\title{
WPS3614
}

\section{WTO Safeguards and Trade Liberalization Lessons from the Argentine Footwear Case ${ }^{1}$}

\author{
by Elías Baracat* and Julio J. Nogués ${ }^{* *}$
}

\section{World Bank Policy Research Working Paper 3614, May 2005}

The Policy Research Working Paper Series disseminates the findings of work in progress to encourage the exchange of ideas about development issues. An objective of the series is to get the findings out quickly, even if the presentations are less than fully polished. The papers carry the names of the authors and should be cited accordingly. The findings, interpretations, and conclusions expressed in this paper are entirely those of the authors. They do not necessarily represent the view of the World Bank, its Executive Directors, or the countries they represent. Policy Research Working Papers are available online at http://econ.worldbank.org.

\footnotetext{
${ }^{1}$ The authors acknowledge the valuable comments of J. Michael Finger to a preliminary version of this paper. We also acknowledge insights gained through conversations with Juan Dumas, President of CAPCICA (Camara Argentina de Producción y Comercio Internacional de Calzado y Afines ), and Carlos A. Litzmann, Manager of CIC (Camara de la Industria del Calzado). Pablo Sanguinetti and other colleagues offered useful comments when this paper was presented in the Seminar on: "Use of Safeguards and Antidumping in Latin America” (Buenos Aires, May 24-25, 2004), organized by the World Bank.

* Independent consultant. Former President of the CNCE (Comisión Nacional de Comercio Exterior) (eliasbaracat@fibertel.com.ar).

*** Professor of “International Trade Institutions and Policies”, Universidad Torcuato Di Tella (jnogues@infovia.com.ar).
} 


\section{Summary}

- The footwear case provides an example of the complexities of WTO rules on the use of safeguards, and of the interaction of multilateral and regional processes of liberalization. As a result both of Argentina's unilateral liberalization and the removal of barriers within Mercosur, imports of footwear increased rapidly. As Mercosur provides no intra-regional safeguard mechanism, the government of Argentina responded by applying import relief and WTO safeguards against third countries. The WTO Dispute Settlement Body addressed these measures and as a consequence, Argentina dismantled most of them, leading to four main conclusions.

- First, the jurisprudence of the WTO’s Appellate Body, has created serious uncertainty as to when a country can use safeguards. This does not contribute to the political balance that has to be maintained when developing countries implement trade liberalization programs; in fact, it detracts from this crucial goal. Second, it is an error to negotiate ambiguous multilateral agreements on the expectation that the WTO Dispute Settlement mechanism will clarify them. Third, an overvalued currency heightened the industry's problems. In the case of footwear, the decline in imports following the recent devaluation was more important than that following the implementation of earlier relief measures. Fourth, the political economy of liberalization also indicates the need for regional agreements to include adequate transition mechanisms that will facilitate adjustment to free trade and to maintain support for it. 


\section{Introduction}

The Argentine experience with the application of safeguard measures in favor of its footwear industry during the country's trade liberalization process is an example of the problems that countries may face when they use this instrument under the rules of the World Trade Organization (WTO). It also offers lessons on rules for adjustment under regional integration agreements.

A traumatic hyperinflation episode at the end of the 1980s was the trigger for the country to carry out a drastic economic reform program that included the unilateral liberalization of trade barriers. These measures were later deepened with the intra-regional liberalization agreed under Mercosur most of which was completed in late 1994. The growth in imports that resulted from these policies, as well as from the overvaluation of the peso associated with the Convertibility law, affected the footwear industry negatively and created economic conditions that apparently justified the application of safeguard measures.

However, the WTO Dispute Settlement Body (DSB) ruled against Argentina's safeguards. Two lessons which come out from this experience are:

- The safeguard rules of the WTO and the jurisprudence of its Appellate Body have problems that create serious uncertainty as to the circumstances under which measures are likely to be contended successfully. This uncertainty does not contribute to the economic transformation of developing countries that consider the implementation of unilateral trade liberalization programs.

- Generally for the economy and particularly for some sectors like the footwear industry, the overvalued currency increased the adjustment costs of the trade liberalization policy.

The remainder of this paper is organized as follows. Section II summarizes the main aspects of the trade liberalization policy implemented by Argentina since the late 1980s. Section III reviews the evolution of the international footwear industry and the impact that 
trade liberalization and currency overvaluation had on this sector. Section IV discusses the import-relief measures applied by Argentina -including the WTO safeguard- in favor of this industry. Section V discusses the main aspects of the dispute brought by the European Commission (EC) to the WTO Dispute Settlement Body (DSB). Section VI analyzes the effects of the 2002 devaluation on footwear trade. Finally, Section VII summarizes the main lessons.

\section{Trade Liberalization and Exchange Rate Policies.}

In what follows we summarize and offer brief comments on the salient issues that provide the background situation in which the safeguard measures were applied, including: i) the unilateral and regional trade liberalization programs, ii) the exchange rate policies and unemployment situation, and iii) trade performance ${ }^{2}$.

\section{Trade liberalization program}

Starting in the late 1980's, trade liberalization policies resulted in a substantial reduction in average protection. Table II.1 provides information on ad-valorem tariff rates as well as the fraction of tariff lines covered with import licenses. The figures show high and increasing protection until 1987-1988, and relatively fast decline thereafter to an average tariff of $18 \%$ in 1989 . This liberalization continued to be deepened during the early 1990s and since then, the average applied tariff has fluctuated between 13\% and 15\%. In addition to these unilateral policies, in 1991 Argentina, Brazil, Paraguay and Uruguay signed the Tratado de Asunción that created the Mercosur (Mercado Común del Sur). With some exceptions, this process of intra-regional trade liberalization was completed in late $1994^{3}$.

\footnotetext{
${ }^{2}$ This section is based on Section II of our paper (Nogués and Baracat, 2005) on the historical experience of Argentina with antidumping and safeguard measures.

${ }^{3}$ For some industries including footwear as we shall see, the tariff dismantling program was extended until the end of 1998 (ALADI 2002).
} 
Regarding export policies, the most significant changes were introduced to export taxes. Historically, Argentina deepened its isolation by imposing high export taxes on agricultural and agro-based products where it has strong comparative advantage. For example, in the mid 1980s export tax collection represented more than $30 \%$ of total exports. From then on, these high tax rates started to decline and by 1992, average collection represented only $1.8 \%$ of exports ${ }^{4}$.

\section{Exchange rate policies}

In March of 1991 the government introduced by law the Convertibility regime that tied the peso to the dollar at par. After that, capital inflows triggered by growing private investment and speculative flows, privatizations of public enterprises and the need to finance continuing fiscal deficits increased the level of foreign debt which eventually reached unsustainable levels. Toward the end of 2001, expectations of devaluation as signaled by the level of country risk increased rapidly and a run against deposits in the banking system accelerated. Eventually in early 2002, the Convertibility regime was abandoned and a major devaluation process began to unfold (de la Torre, Yeyati and Schmukler, et. al. 2003).

During most of the 1990's, capital inflows resulted in an important overvaluation of the peso. Figure II.1 shows the time-path of the real exchange rate (RER) against the dollar ${ }^{5}$; the numbers indicate a strong reduction of the average level during the Convertibility years from 1991until 2002. This currency overvaluation increased the adjustment challenges to the trade liberalization program faced by domestic producers in some cases like the footwear industry quite dramatically (Nogués and Baracat 2005).

\footnotetext{
${ }^{4}$ The policy of essentially no taxes on exports continued until the devaluation of 2002 when in an emergency situation, they were re-imposed. In the early 90's, financial subsidies granted to non-competitive manufactured exports were also dismantled (Nogués 2001).

${ }^{5}$ The RER is estimated as the nominal exchange rate times the ratio of the U.S. to Argentina's cost of living indexes.
} 


\section{Growth and unemployment}

During the 1990’s, Argentina was hit by several negative external events including: i) the Tequila effect that started in late 1994, ii) the Asian crisis in 1997, iii) the Russian default in 1998 and, iv) the reduction of international commodity prices in the second half of the 1990's. A slight recession occurred when adjustment measures were implemented in 1995 to lower vulnerability to the Tequila crisis. Otherwise, the economy could generally cope well with the negative effects of these events and continued growing until mid-1998. Nevertheless, since then, first the increasing stock of foreign debt and accompanying growing levels of country risk and the Brazil devaluation in early 1999 implied that starting in late 1998, the economy entered into a prolonged period of recession that lasted until late $2002^{6}$.

Another important aspect of the macroeconomic scenario was the continued high rates of open unemployment. In 1993 and for the first time in years, the unemployment rate surpassed the $10 \%$ level to reach nearly $20 \%$ in 1995 , declining thereafter to around $15 \%$.

\section{Trade response}

The major reduction in import barriers resulted in an important increase in trade flows. Figure II. 2 shows that imports increased from less than \$5 billion dollars in the late 1980 's and early 1990`s, to more than \$20 billion dollars in 1994-95, and more than \$30 billion dollars in the late 1990's. During this same period, exports increased from around six billion dollars to more than 26 billion in the late1990s.

\section{Summing up}

Argentina's trade liberalization policies of the early 1990s were significant and played a major role in changing the economic trends of the country. Until 2001-2002, when

\footnotetext{
${ }^{6}$ Starting in 1990, Argentina's economy recorded the following growth rates (\%): 1990: -2.4 ; 1991: 12.7; 1992: 11.9; 1993: 5.9\%; 1994: 5.8; 1995: -2.9; 1996: 5.5; 1997: 8.1; 1998: 3.9; 1999: -3.4; 2000: -0.5; 2001: 4.4; 2002: -10.9 and, 2003: 8.4.
} 
trade policies were partially reversed, the economy underwent the longest period with an open trade regime that it has seen in several decades. In spite of the strong convertible peso that lasted until late 2001, the trade response to these liberalization measures was vigorous and import competition increased significantly. It was during these years when several sectors, including the footwear industry, petitioned for safeguards ${ }^{7}$.

\section{The Footwear Industry and the Impact of Liberalization}

The evolution of the footwear industry in the second half of the 20th century is an interesting example of the transformation process of labor-intensive industries and of the migration of manufacturing activities to developing countries with an abundant labor supply. In a few decades specialization along comparative advantage lines implied that the production of footwear that used to be a traditional activity in many countries became a productive world network with functions spread over several countries (Gereffi 2001). As a result, international footwear trade came to represent a growing share of world production.

Under growing international specialization, the migration of manufacturing to developing countries has advanced uninterruptedly and in the course of relatively few years, the main exporters changed. Countries that were investment receivers and major footwear exporters, like Japan in the 1950s and later Korea and Taiwan in the 1960s, were displaced by China in the 1990s. More recently countries like Vietnam, India, Egypt and some countries in Eastern Europe and Central Asia are also gaining prominence ${ }^{8}$. The lesson here is that competitiveness of the footwear industry is highly dependent on labor costs. In the ladder of decreasing labor costs, Argentina is not precisely close to the top.

\footnotetext{
${ }^{7}$ Nogués and Baracat (2005) review this experience and conclude that over time overvaluation increased the likelihood of arriving at positive injury determinations.

${ }^{8}$ According to Shetty (1995), by the mid 1980s, Taiwan and Korea represented 45\% of world footwear exports but by 1994 their share had decreased to 7\%. By contrast, China that in 1979 only represented 1\%, in 1994 had a 50\% share of world footwear exports.
} 


\section{Domestic industry}

Argentine footwear manufacturing was born several decades before the country embarked on the import-substitution strategy for industrialization ${ }^{9}$. However, as was the case with most manufacturing industries, starting in the late 1940s, footwear production became highly protected. After that, both imports and exports were sporadic and never represented significant shares of domestic production ${ }^{10}$.

The CNCE (Comisión Nacional de Comercio Exterior), which is responsible for safeguard investigations ${ }^{11}$, estimated that in 1991, footwear production amounted to 71.4 million pairs. In turn, the National Economic Census of 1994 shows a total of 27,177 people employed by this industry ${ }^{12}$, whereas the 1985 census showed a total employment of 31,596 people. As for the number of industry producers, the National Economic Census of 1994 revealed a total of 1,554 factories, out of which 998 manufactured leather footwear; 292 produced footwear made of fabric, plastic and other materials; and 264 produced footwear parts. In 1985, the census recorded 2,211 factories.

The footwear industry has two clearly differentiated segments - sports footwear and non-sports footwear. As we shall see, these differences had an impact on the safeguard measures that would and would not be considered illegal under WTO rules. The first segment represents the largest part of the industry and most of the companies that are part of it employ less than 10 workers each.

\footnotetext{
${ }^{9}$ The development of the cold storage industry since the end of the 19th century favored meat exports which in turn, increased the supply of leather, the main raw material of this industry.

${ }^{10}$ As a comparative reference, it can be pointed out that in 1992, Italy exported $81 \%$ of its footwear production, Brazil exported 30\% and Argentina exported only 3.5\%.

${ }^{11}$ The CNCE was created in 1994 and assigned the responsibility for the injury investigations in antidumping, subsidy and safeguards investigations. Knowing that the injury test was the instance that stopped protectionist demands, the goal of the policymakers that created the CNCE, was a highly professional office that would filter the deserving from the undeserving petitions (Nogués and Baracat 2005).

${ }^{12}$ The distribution of employment was as follows: leather footwear, 14,236 workers, footwear made of fabric, plastic and other materials, 9,264 workers, and footwear parts, 3,677 workers. Due to the atomization that characterizes the industry, statistics are not as accurate as for other sectors.
} 
Because of the materials used, the relatively sophisticated technology, the scale of industrial plants and consumer preferences, sport footwear is different from leather footwear and was born several decades after. When on the basis of well-known international brands the sports footwear industry became "globalized" in the 1980s, Argentine producers obtained producing licenses to manufacture and sell these brands in the domestic market ${ }^{13}$.

\section{The impact of trade liberalization}

The reduction of trade barriers to footwear imports started to be implemented in 1988. First, unilateral trade liberalization reduced the average tariff faced by the industry from 53\% in 1988 , to $22 \%$ in 1991 . The significant reduction of export taxes on raw leather also reduced effective protection faced by domestic producers (Bekerman et al., 2000). Second, despite the fact that footwear was given a longer implementation period until 1998, the creation of Mercosur triggered rapidly increasing imports from Brazil, a major world exporter of non-sports footwear ${ }^{14}$.

What was the impact of this trade liberalization? The traditional forecast that predicted that Argentina could become an important footwear exporter, because it was an efficient leather producer and had a good quality footwear industry, proved to be wrong. Reality showed that the comparative advantage that the country had in leather was a less important determinant of international competitiveness than labor costs ${ }^{15}$.

\footnotetext{
${ }^{13}$ Thus, at the beginning of the 1990s, there were three dominant sports footwear producers - Alpargatas Calzados, Gatic and Unisol, which together employed a little more than 10,000 workers and represented one third of the total pairs of all types of footwear produced by the industry.

${ }^{14}$ Starting in the 1970s, the Brazilian industry experienced a remarkable expansion. The availability of abundant raw material and relatively low wages favored the development of clusters that became highly efficient. In the early1990s this industry comprised 8,500 companies, which employed more than 300.000 workers (Salazar de Buckle, 2001, and Bekerman et al., 2000).

${ }^{15}$ In this industry, the incidence of labor costs is very important. For example, the national economic census of 1994 shows that in 1993 salaries represented 59.3\% of gross value added in leather footwear manufacturing, $58.8 \%$ in the case of footwear made of fabric, plastic and other materials, and $57.8 \%$ in footwear parts manufacturing. It is important to stress that due to currency overvaluation, during the1990s, labor costs increased significantly in relation to previous decades (Section II).
} 
The process that was triggered by the trade liberalization program is presented in Graph III.1, which shows total imports of footwear and footwear parts. Although during the 1980s these imports were almost non-existent, from 1991 onward, there was a rapid growth. Exports had also been scarce, but starting in 1987, some growth is recorded. As Graph III.2 shows, this process became stronger in the 1990s when exports temporarily reached 100 million dollars/year.

To a good extent, the rise in exports was due to government promotion policies and here, the industrial specialization regime was particularly important. This program supported the internationalization of production, by granting exporting companies an import quota paying a reduced $2 \%$ tariff for imports coming from a different tariff line than the one under which exports were recorded. On the other hand, exports of footwear parts have been very much linked to the changes in export taxes on leather, and reimbursements to exports of footwear parts (CNCE 1997). Because this export promotion program was not sustained, during the second half of the 1990s, exports declined as support programs were terminated, the currency became overvalued, and leather export taxes significantly reduced.

As Table III.1 shows, competitive pressures on the domestic industry heightened ${ }^{16}$ as imports grew to 8.9 million pairs in 1991, 16.6 million pairs in 1992, and 21.8 million pairs in 1993 when they represented around one-third of domestic production. The main exporters to Argentina were Asian countries and Brazil.

Consequently, the trade liberalization and accompanying policies deteriorated the competitive position of this industry, which it tried to reverse through an adjustment and modernization strategy that was supported by government policies, particularly safeguard measures.

\footnotetext{
${ }^{16}$ The figures shown on Table III.1 correspond to the tariff positions for which the CIC requested safeguard measures.
} 


\section{Import-relief Policies and WTO Safeguards for the Footwear Industry}

Eventually, the response of policymakers to growing pressures for import relief was positive: the unemployment that might be caused by the collapse of the major producers was perceived as too high a political and social cost. This was the typical case when taking one step backward was perceived as a politically necessary action in order for later taking two steps forward and protecting the trade liberalization program $^{17}$.

\section{Pre-Uruguay Round import-relief measures}

The trade instrument initially chosen in order to offer import relief was the so-called “minimum specific import duties” (DIEMs, or derechos de exportación específicos mínimos), approved in December 1993, for both the sports footwear industry and the textile industry. The DIEM are dollar values applied as a specific duty per pair of imported footwear. When the application of the applied ad-valorem duty renders a higher value than the DIEM, the former is applied. Otherwise, the DIEM is charged.

The use of this instrument by the government was based on the low price of imports and the damage that this caused to the Argentine industry. Likewise, the norm indicated that this measure was temporary and that it was linked to an investment plan for the readjustment and specialization process of the benefited industries ${ }^{18}$. In other words, although the safeguard philosophy underlies the measures, they were not implemented under GATT article XIX, which was still in force at that moment.

\footnotetext{
${ }^{17}$ The traditional footwear industry was located in the main urban centers, while the three major sports footwear manufacturers had located their eighteen plants in regions that were removed from the major consumption cities, and here, they were important major if not the most important employers (CNCE 1997). Obviously the high employment dependency in these locations which generally were relatively poor areas, increased the political visibility of the petition. This visibility was also heightened by the rapidly increasing unemployment of the1990s (Section II).

${ }^{18}$ Policymakers knew about the re-conversion efforts of the industry and they in turn promoted its technological upgrading by fixing a zero tariff for imports of capital goods. According to Cerutti (2003), between 1991 and 2000 the industry invested a total of 541 million dollars, or an annual average of 54 million dollars, a figure equivalent to 5\% of the production value and 13\% of the value added. Between 1996 and 1998, investment in machineries reached 76 million dollars per year.
} 
It is worth noting that under the Treaty of Asunción (1991), which created Mercosur, safeguards are not allowed. Accordingly, the DIEMs were not applied on imports coming from Brazil. Within Mercosur, regional imports of footwear were subject to a tariff reduction schedule that converged to zero in late 1998.

At first, the DIEMs against imports from third countries were fixed as an exceptional measure for a year, but later they were extended and their scope widened. However, in February 1997, three years after they were initially applied, Argentina abolished them and simultaneously, announced the initiation of an investigation that would determine the need for the application of safeguard measures in accordance with the rules of the new Uruguay Round Agreement on Safeguards and Article XIX of GATT 94. When the investigation was launched, Argentina established provisional safeguard measures consisting in new DIEMs, which were almost identical to the ones that had been abolished.

The decision to initiate an investigation under WTO rules was triggered by consultations requested by the United States and the European Commission (EC) under the WTO dispute settlement regulations. These consultations referred to the compatibility of the DIEMs on textiles and footwear with the tariff-ceiling binding by Argentina in the Uruguay Round $^{19}$. These countries argued that in many cases, the DIEMs were higher than the 35\% that Argentina had binded in the WTO. As the DIEMs on footwear were abolished after consultations were requested, this dispute limited its scope to textiles ${ }^{20}$.

In summary, for a few years Argentina used the DIEMs as a unilateral de facto safeguard measure. When they was first applied in late 1993 after imports increased 2.5 times from 1991 (Table III.1), the country had not consolidated a maximum tariff of 35\% and therefore, it enjoyed a wide margin of action to set tariffs. Probably under the belief that the Agreement on Safeguards that at the time was being negotiated would eventually provide the legal basis to sustain its "safeguard" measures, Argentina did not negotiate a

\footnotetext{
${ }^{19}$ Decree 1,059/96 had previously regulated the application of safeguard measures under the Agreement on Safeguards, under which the country processed the WTO safeguard petitions (Nogués and Baracat 2005).

${ }^{20}$ The consultation request by United States in October 1996, led to the Special Group "Argentina - Medidas que afectan a las importaciones de calzado, textiles, prendas de vestir y otros artículos" (Argentina Measures that affect imports of footwear, textiles, clothing and other articles), which established the incompatibility of the DIEMs with the commitments made by the country in the Uruguay Round. Later in March 1998, the Appellate Body arrived at the same conclusion.
} 
market reserve at the Uruguay Round. Within Mercosur, the error in political calculus was associated with the Tratado de Asunción that, after a short adjustment period, banned the use of safeguards for regulating intra-regional trade flows. Nevertheless at the time when this Treaty was signed in 1991, imports triggered by the unilateral trade liberalization program were still much lower than the levels they would reach two years later. Failure to negotiate regional safeguards would, in later years, severely limit the acting capacity of the government and industry ${ }^{21}$.

\section{WTO safeguards by Argentina}

Although during its trade liberalization process Argentina was cautious with the administration of measures under GATT Article XIX and the Agreement on Safeguards, in the few cases where it attempted to use them, the decisions by the WTO Appellate Body almost totally ruled them illegal. Two of only three cases where the government implemented WTO safeguards were finally eliminated by decisions taken by this Body.

The CNCE has received 13 petitions for WTO safeguards of which: i) seven were turned down before initiation, ii) one was withdrawn by the petitioner, iii) one was returned to the petitioner on the basis of insufficient information and, iv) four resulted in the opening of investigations. Safeguard measures were introduced in three of them: footwear, canned

\footnotetext{
${ }^{21}$ This vacuum in the Mercosur contrasts with the ability of other regional agreements like the Andean Community and the Central American Common Market (Reina 2005). It also contrasts with market reserves negotiated by industrial countries for their footwear industries. For example, in 1993 Japan applied quotas for leather footwear imports and also fixed custom duties according to material used. Since 1994, the European Union applied a system of quotas on imports from China and Hong Kong and there also was an antidumping measure on Chinese footwear imports of around 50\%. (European Confederation of the Footwear Industry, 1995) The US is the country that is more open to imports, and this has resulted in an almost total migration of manufacturing activities to developing countries (Shetty 1995, American Apparel \& Footwear Association, 2004 and US. International Trade Commission, 1999). On the other hand, several developed countries enjoy escalation in their tariff structures (CNCE 1997 and Trade Development Council, 2003). In referring to the case of developed countries in the Tokyo Round, Hufbauer and Elliot (1994, page 66) expressed that in some footwear categories "Ad valorem rates ...remained dutiable at the Smoot-Hawley rate of 25 to 37.5\%. Ad valorem duties on casual footwear (e.g., athletic footwear, sport oxfords, sneakers, and espadrilles) currently range from 20 to $67 \%$..." Concerning the effects of the Uruguay Round, these authors state that "the evidence indicates that the footwear industry in industrial countries emerged relatively unscratched". Supporting this view, de Paiva Abreu (1996 page 66) asserts that while the average tariff reduction implemented by developed countries on industrial products was $28 \%$, the reduction for footwear imports was only $6.1 \%$ i.e., the lowest among the sample of industries included in this study.
} 
peaches and small motorcycles. In the fourth case, the toy industry, the CNCE determined at the end of the investigation that safeguards were not applicable.

Of the three cases with measures, two were taken to the WTO Dispute Settlement Body: footwear and canned peaches. Footwear was the most visible case and here the Panel and the Appellate Body issued negative decisions. Argentina also lost the canned peach dispute and had to remove the safeguard measures (Nogués and Baracat 2005).

The evidence from Argentina's experience with safeguards under GATT Article XIX and the Agreement on Safeguards suggests that the government tried to operate the rules as a truly economic instrument to facilitate the adjustment of industries damaged by increased imports. Nevertheless, it was unsuccessful. Why? The general point here, well argued by Sykes $(2003)^{22}$, is that the WTO dispute settlement process never found a thread of economic reasoning on which to build its interpretations against safeguards, but it did have the effect of preventing Argentina from attempting to put into effect its interpretation of economic application. The footwear case supports Sykes’ conclusions.

\section{Petition for safeguard measures}

The safeguard investigation was triggered by a petition from the CIC that, as said, represents small non-sports footwear producers. This petition was supported by the major sports footwear manufacturing firms, which paid for the legal professional assistance that was hired in the United States. These costly services were initially entrusted with bringing the case before the CNCE and later they were used to defend Argentina in the WTO case.

International sports footwear firms as well as some nonsports footwear producers acted in defense of imports. Under increasing labor costs associated with currency overvaluation, the latter had partially abandoned their local production to target their

\footnotetext{
22 "In the absence of any coherent theory as to when safeguards should be allowed, it is absurd to expect WTO members to produce a 'reasoned and adequate explanation as to how their measures are in compliance with the law” (Sykes 2003).
} 
business on traditional and casual footwear imports retailed under their own brands or international brands ${ }^{23}$.

The decision to open an investigation in February 1997 included the application of provisional measures, as the CNCE determined that eliminating the DIEMs without an alternative measure to curb imports would recreate critical circumstances for the industry. To reach such a conclusion, it estimated the effectiveness of the DIEMs to curb imports ${ }^{24}$, thus linking the de facto safeguard applied from late 1993 to early 1997 with the WTO safeguard. In September 1997 the CNCE arrived at a positive determination and definitive measures were implemented. During 1998, these measures were made more restrictive ${ }^{25}$.

The major opposition to Argentina's safeguard measures did not come from the major exporting countries like China, but from the countries where the firms that own the major brands are located. The political economy of this case can be explained by the globalization process of the industry, particularly the sports footwear segment, which is characterized by the existence of multinational firms that manufacture in low-wage countries, with designs and technology usually developed in their developed countries. This characteristic illustrates how an instrument like safeguards that regulates the trade between the domestic and foreign producers decided on a case where local production confronted the interests associated with the ownership of intellectual property like designs and brands in this case, European companies.

\footnotetext{
${ }^{23}$ This group of companies and interests had joined in CAPCICA, whose creation in 1996 was triggered by the safeguard investigation before the CNCE.

${ }^{24}$ The CNCE used an UNCTAD simulation model estimating that in the absence of the DIEMs, footwear imports would increase by at least $26 \%$.

${ }^{25}$ Given the nature of the DIEMs, the incentive is to import higher quality and priced footwear. This "flight to quality" illustrated by the increasing unit prices in Table III.1, reduced the ad-valor equivalent of the DIEMs. The adjustments implemented during 1998 addressed this problem by raising the specific duties and fixing quotas by tariff position.
} 


\section{The WTO Dispute and the Determinations of Its Appellate Body}

In April 1998, the EC requested consultations with Argentina in the framework of the WTO Dispute Settlement Body. Because these consultations did not deliver an understanding, a Special Group was appointed and in June 1999, it issued its definitive report in the case: "Argentina - Safeguard Measures on Imports of Footwear”. In November, the Appellate Body stated the following: "The Appellate Body recommends that the DSB request that Argentina bring its safeguard measures found in this Report and in the Panel Report as modified by this Report, to be inconsistent with the Agreement on Safeguards, into conformity with its obligations under that Agreement”.

There are three aspects of the case that are important to consider in the context of this paper: i) the economic and political problem underlying the dispute, ii) the determinations of the Special Group and the Appellate Body and, iii) the impact on and the response by Argentina.

\section{Political economy of the safeguard measure}

As mentioned before, since late 1993, the DIEMs operated as a de facto safeguard $^{26}$. It is clear that this action represented a step backward in the liberalization program but this was done to soften adjustment costs and most importantly, to maintain political support for the broader policies. Although the application of the DIEMs was not legally based on GATT Article XIX, at the time when the measures were introduced in late 1993, they did not violate any of the multilateral rules. The measures adopted in favor of two labor-intensive industries (textiles and footwear) worked as an element of political balance in the framework of a major structural reform program which, as mentioned in Section II, was accompanied by a strong growth of imports and increasing unemployment rates.

\footnotetext{
${ }^{26}$ In the context of its description of the "facts and background of the procedure" before the Special Group “Argentina - Measures that affect imports of footwear, textiles, apparel and other articles," the EC alleged that "In fact, Argentina was applying a safeguard measure without complying with any of the procedures established in the WTO Agreement applicable as from January $1^{\text {st }} 1995$.” In other words, the EC recognized that Argentina was applying a safeguard measure.
} 
However, once the commitments of the Uruguay Round were accepted, in which Argentina binded the maximum tariff at 35\%, a conflict arose between the measures in existence and the new rules. By initiative of the United States and the EC, the WTO dispute settlement system was activated, and in the end most of the measures had to be dismantled.

The first case, “Argentina - Measures that affect imports of footwear, textiles, apparel and other articles" (See Section IV.2), was initiated by the United States and as said, this case ended with Argentina eliminating the measures in favor of textiles and apparel. ${ }^{27}$ Then, when Argentina's CNCE arrived at a positive determination in favor of the footwear industry, the EC initiated a second case (WTO 1999).

Argentina's experience with these measures was certainly discouraging in relation to the use of WTO safeguards. However, the decision of the Appellate Body coincides with those it has later taken in other cases. As a result, this Body has established a jurisprudence that is against the use of WTO safeguards, both for developing and developed countries. However, if we consider that in the last decade most safeguards were applied by developing countries, during strong unilateral trade liberalization programs, this jurisprudence is acting against the implementation of further liberalization programs. The political economy of the Appellate Body's decisions on safeguards reinforces the arguments of those who are against liberalization.

\section{Determinations by the WTO Appellate Body}

The EC argued that Argentina’s investigation did not prove an increase in imports, nor injury and causality, and that consequently, it acted in violation to the WTO rules. The EC also alleged that the provisional and definitive safeguard

\footnotetext{
${ }^{27}$ Let us reiterate that the argument was that in many cases ad-valorem duties equivalent to the DIEMs surpassed the maximum tariff of 35\% that was consolidated by Argentina in the UR.
} 
measures were not the result of unforeseen developments, and that they also constituted an infringement of WTO rules ${ }^{28}$.

Both the Panel and later the Appellate Body adopted a similar criterion to that of the EC, in the sense of analyzing compliance with the rules without linking the argument to the existence of a program to curb imports, which as said, was undertaken in the context of a far-reaching unilateral liberalization program undertaken before the Uruguay Round agreements were signed.

As said, the jurisprudence of the Appellate Body in this and other safeguard cases has been strongly criticized by Sykes (2003). His conclusion is that the texts of Article XIX and of the Agreement on Safeguards fail to orient an investigation for the application of a measure, and that this has not helped to establish reasonable criteria. Consequently, this author concludes that "given the lack of a coherent theory on when a safeguard should be allowed, it is absurd to expect WTO members to produce a reasonable and adequate explanation that their measure is in compliance with the law."

In the remainder of this section we analyze two points in the dispute the interpretation of the concept "unforeseen developments" which is in the text of Article XIX of GATT 1994, and the treatment of imports from Mercosur.

\section{$\underline{\text { Unforeseen developments }}$}

The EC alleged that in order to apply safeguard measures it is not enough to record an increase in imports that cause serious injury, as the Agreement on Safeguards establishes, but that it is also necessary that such increase be the result of

${ }^{28}$ The EC alleged that Argentina had infringed the following provisions:

- $\quad$ article XIX of GATT 1994 (in particular, on "unforeseen development of circumstances") ;

- $\quad$ and the following provisions of the Agreement on Safeguards:

a) article 2 (especially the obligation to determine that certain conditions are met by means of an investigation, as well as the obligation of no discrimination); b) article 4 (in particular, the obligation to assess all relevant factors and to prove the existence of a causal relationship); c) article 5 (especially the requirement that only measures to prevent or repair severe damage should be applied); d) article 6 (in particular, the obligation to prove the existence of "critical circumstances"); and e) article 12 (especially notification obligations). 
“unforeseen developments” as established by GATT Article XIX $(1 \mathrm{a})^{29}$. In other words, this development should take place after the relevant tariff reduction, and, within what was reasonable to expect in the moment of making the concession, negotiators neither could nor should have foreseen that the development would take place. More specifically:

"The European Communities argues that it clearly results from the wording of Article XIX:1(a) GATT that in order to allow the imposition of a safeguard measure, not any increase in imports is relevant, but only those which result from both "unforeseen developments" and "compliance with GATT obligations", including tariff liberalisation according to a party's Schedule of Concessions. Since tariff concessions and other obligations are an additional element to "unforeseen developments", it necessarily follows that liberalisation cannot constitute by itself such unforeseen developments. The European Communities submits that Argentina's trade liberalisation, in particular within the Mercosur and WTO framework, was a conscious commercial policy. The development in trade since 1991 - particularly since the signing of the Treaty of Asuncion - is the natural result of the commercial policy followed by the Argentine government and that this and the illegality of the trade protection measures which preceded the safeguard measures the subject of these proceedings, were in no way unforeseen. Argentina therefore violated Article XIX:1(a) GATT” (WTO 1999 para. 1.4, emphasis added).

With this argument, the EC disqualified the important increase in imports recorded between 1991 and 1993 (Table III.1). According to this argument, the increase in imports was "foreseen" by authorities at the moment of implementing the unilateral trade liberalization policy as well as the binding of a maximum tariff of 35\% in the Uruguay Round. Argentina argued that the concept of "unforeseen developments” is subjective and was purposely removed by the negotiators from the text of the Agreement on Safeguards. The country also argued that the interpretation of the EC would discourage trade reform processes, as it would presume that a

29 This Article sates that: "If, as a result of unforeseen developments and of the effect of the obligations incurred by a Member under this Agreement, including tariff concessions, any product is being imported into the territory of that Member in such increased quantities and under such conditions as to cause or threaten serious injury to domestic producers in that territory of like or directly competitive products, the Member shall be free, in respect of such product, and to the extent and for such time as may be necessary to prevent or remedy such injury, to suspend the obligation in whole or in part or to withdraw or modify the concession. (emphasis added). 
country should foresee all developments when it takes trade liberalization policies ${ }^{30}$.

Among others, Argentina also argued:

"For Argentina, it should also be borne in mind that in fact, the CNCE found in its final determination that there had been unforeseen circumstances when it states that "The pressure exercised by imports was unforeseen in its rapid progress in the market during a period in which the country's economy was beginning to suffer from macroeconomic difficulties." Imports achieved and preserved a considerable share of the domestic market, and even in 1995, they continued to preserve their share in a rapidly declining market. The rapid growth in imports at the beginning of the period was also unforeseen, and particularly significant since the rate of growth was much higher than that of overall imports between 1991 and 1993.

Finally, in Argentina's view, the significance of the different impacts of imports on the footwear industry could not have been foreseen. The comparative GDP data clearly shows that the footwear industry was affected disproportionately in relation to the manufacturing sector as a whole" (WTO 1999 para. 1.5).

On this point, the Special Group sided by Argentina as it resolved that the safeguard measures applied after the effective date of the Uruguay Round Agreements complied with the requirements of GATT 94 Article XIX. More specifically: “... it is our conclusion that safeguard investigations conducted and safeguard measures imposed after the entry into force of the WTO agreements which meet the requirements of the new Safeguards Agreement satisfy the requirements of Article XIX of GATT. Therefore, we see no basis to address the EC's claims under Article XIX of GATT separately and in isolation from those under the Safeguards Agreement.” 31.

However, the Appellate Body decided to revoke this conclusion and determined that Uruguay Round negotiators “deliberately omitted” the expression "as a result of unforeseen developments...," and supported the total validity of the text of Article XIX (1) of GATT $94^{32}$. According to the Appellate Body the legality of safeguards hinges on compliance with both the requirements of GATT 94 Article XIX, and the Agreement on

\footnotetext{
${ }^{30}$ On the point on unforeseen developments, Sykes (2003) argues that the fact that GATT Article XIX (1) is not mentioned in the Agreement on Safeguards makes one doubt that "the drafters of the Uruguay Round Agreements had any intention of reviving it: had they wished to alter existing GATT practice in this respect, they would have so indicated with clarity”. This was obviously the argument held by Argentina.

${ }^{31}$ Panel Report, para. 79 (WETO 1999).

${ }^{32}$ On this decision to revive Article XIX (1) of GATT, Sykes (2003) argues that the Appellate Body should have at least explained its specific requirements: "At what point in time must the events in question have been unforeseen: the time of the last tariff concession? What if the last concession on the product was decades ago - could anything today have been foreseen? And other questions alike” (page 277).
} 
Safeguards ${ }^{33}$. Later determinations made by the Appellate Body in other cases have reaffirmed this interpretation.

On this point Sykes (2003) argues that the original text of Article XIX (1) of GATT made sense in the early historical context of 1947 when the founding fathers of the multilateral trade system foresaw that in order to manage the political pressures that would arise from multilateral trade liberalization required the existence of a safeguard mechanism. However, having elapsed decades since 1947, safeguards began to be established, not for "unforeseen" effects of tariff concessions but simply as a response to problems associated with important increases in imports that cause serious injury to the industry ${ }^{34}$.

In spite of the ambiguity of the rules, the Appellate Body has not established a theory on when imports can be seen as a causal variable of injury, leaving member countries without a guide on when safeguards are allowed or not. In the case of Argentina, the rapid growth of imports triggered by its unilateral policies justified the first de facto import-relief measures (the DIEMs). In this regard, the positive determination by the CNCE for WTO safeguards, led to measures that represented the continuity of the earlier import-relief measures.

Broad unilateral trade liberalization programs like those implemented by many developing countries should constitute the base against which to assess the increase in imports and the implementation of relief measures. Under these types of programs, there will always be unforeseen developments and adjustment processes of uncertain duration. With the WTO jurisprudence that has been established by its Appellate Body, developing

\footnotetext{
${ }^{33}$ More specifically, the Appellate's Body conclusion was: “In the light of all of this, we do not agree with the Panel that any safeguard investigations conducted or safeguard measures imposed after the entry into force of the WTO Agreement "which meet the requirements of the new Safeguards Agreement satisfy the requirements of Article XIX of GATT." (emphasis added) Therefore, we reverse the Panel's conclusion in paragraph 8.69 of the Panel Report that safeguard measures imposed after entry into force of the WTO Agreement which meet the requirements of the Agreement on Safeguards necessarily "satisfy" the requirements of Article XIX of the GATT 1994, as well as the Panel's finding that the Uruguay Round negotiators "expressly omitted" the clause - "as a result of unforeseen developments and of the effect of the obligations incurred by a Member under this Agreement, including tariff concessions ... " - from Article 2 of the Agreement on Safeguards" (WTO 1999a, para. 97).

${ }^{34}$ Note that over time, trade policy (say a tariff reduction) looses relevance as an exogenous variable that determines the changes in imports. In this regard, WTO rules are left with no reference level against which variations in the value of imports can be established.
} 
countries have been stripped of a powerful argument to convince their political sectors of the advantages of opening their economies ${ }^{35}$. In the case of Argentina, another negative consequence of this jurisprudence has been a tendency to shift petitions for import relief to the antidumping mechanism (see Nogués and Baracat, 2005) which in some cases is operating as a substitute safeguard mechanism (see Finger, 2002).

\section{Exclusion of imports from Mercosur}

The EC objected that Argentina's investigation was based on statistics on total imports, while safeguard measures were applied only on imports from third countries. The EC did not reject the right to exclude Mercosur countries from the measures as long as exports from this region were also excluded from the analyses of the "increase in imports," "serious injury" and the "causal relationship".

Argentina alleged that its investigation considered imports from Mercosur and from third countries separately, but concluded that trade diversion from Mercosur and exclusion of intra-regional trade from payment of the DIEMs, in their absence and as a consequence of the unilateral liberalization, had resulted in an increase in total imports. Table V.1 shows that an important part of the increase in imports from Mercosur occurred after the application of the DIEMs on products from the rest of the world, whereas until 1993 when Mercosur was still in the formative stage, the evolution was very similar between both trade flows.

Clearly, an effective safeguard would have required measures against imports from all origins but the Treaty of Asunción had banned its use ${ }^{36}$. However, the argument held by Argentina showed that had the DIEMs not been in place, imports from all origins would have risen, as it happened between 1991 and 1993. In this case, a safeguard only against third countries represented a weak control measure but at least one that helped to indicate that whenever the unilateral liberalization created serious social problems, the government

\footnotetext{
${ }^{35}$ Sáez (2005) explains how, in the case of Chile, the approval of a safeguards mechanism was the argument used by the Executive before the Congress to get approval for a general Customs tariff reduction from $11 \%$ to $6 \%$ in five years.

${ }^{36}$ Nogués and Baracat (2005) argue that this decision has led to a greater use of antidumping measures on intra-regional trade.
} 
would act. The WTO rules prevented the functioning of this delicate political argument to hold in favor of open trade.

The Appellate Body determined that the measure applied by Argentina was national and not a Mercosur measure on behalf of a member country. This Body also concluded that the investigation carried out by Argentina could only lead to the application of safeguard measures to imports from all sources ${ }^{37}$.

Summing-up, the determinations by the Appellate Body concluded that Argentina was not able to prove an increase in imports, serious injury and causality. Concerning the first aspect, under the "unforeseen argument" the recent evolution of imports was given priority over the process that started in 1991 with the unilateral trade liberalization policies. The Appellate Body concluded that to merit measures, the increase in imports must be the result of "unforeseen developments" and also that it must be "recent, unexpected, serious and important enough, both quantitatively and qualitatively, to cause or threat to cause a "serious injury." As indicated at the beginning of this section, the WTO Dispute Settlement Body approved the reports, conclusions and recommendations of the Appellate Body.

\section{Impact on and response by Argentina}

In the medium to long run, this and other WTO decisions against Argentina's safeguard measures has led the business community to rely more on the antidumping mechanism (Nogués and Baracat 2005). Nevertheless, there were also some short-run decisions that were taken in order to strengthen support for the trade liberalization program from the negative shock it had received from the WTO Appellate's Body decisions. In particular, in January 2000 the Secretariat of Industry, Trade and Mining requested the CNCE to review the analysis of imports and serious injury that it had determined for this case in June 1997. Based on the new findings, it requested the CNCE to analyze the possibility of maintaining measures for at least some footwear products.

\footnotetext{
${ }^{37}$ Pauwelyn (2003) points out that in some cases the Appellate Body accepted that a measure against third countries can be justified in an investigation on total imports, if authorities explicitly establish that imports from third countries cause or threat to cause serious injury to the industry (page 120).
} 
The central problems to solve were: a) to prove an import growth that could be considered unforeseen, recent, unexpected, serious and important, both quantitatively and qualitatively; b) to eliminate imports from Mercosur; and c) under the new evidence, to prove serious injury and causality. The review performed by the CNCE found grounds to implement a safeguards for sports but not casual and leather footwear. As said, this type of footwear was produced by a small group of very large companies located in remote cities and that competed with imports coming mostly from outside the Mercosur.

On February 2000, the CNCE decided to eliminate the safeguard for non sports footwear $^{38}$, and the measures for sports footwear were provisionally extended for 150 days, while the investigation was completed. Finally, the CNCE arrived at a positive determination and on July 2000 it extended the safeguard measures for three years which expired in July 2003.

\section{Conclusion}

Both due to its ingenuity and to ambiguous multilateral treaties and rules, Argentina was not able to establish stable and predictable safeguards in favor of its footwear industry. The country failed to negotiate exceptions both in the Uruguay Round, and in the Mercosur, where there could have been regional safeguards as those that for example operate in the Andean Community (Reina 2005). It is likely that Argentina's policymakers concluded that the safeguards that were being negotiated in the Uruguay Round when the DIEMs were implemented would be applicable to the textile and footwear industries. As to the multilateral system, the lesson is that it is a mistake to negotiate ambiguous agreements on the expectation that its Appellate Body will later clarify matters. In this case, the ambiguity is working against trade liberalization programs.

\footnotetext{
${ }^{38}$ On the same date, the DIEMs for non sports footwear were re-established, now subject to verification that they do not surpass the limit of an equivalent ad-valorem tariff of $35 \%$ for imports coming from third countries.
} 


\section{Devaluation and Recent Evolution}

As observed in Graphs VI.1 and VI.2 (a, b and c), until the early 2002 devaluation episode, the safeguard measures of 1997 did not reduce imports below the levels reached in 1995. On the contrary, footwear imports continued growing reaching approximately $\$ 180$ million dollars per year just before the devaluation (Graph VI.1a). However, after 1998, the safeguard measures apparently reduced imports from third countries while at the same time diverting imports toward Mercosur that around 2000-2001 accounted for approximately $80 \%$ of the total.

This trade diversion effects were heightened by the devaluation of the Real in early 1999 which caused regional footwear imports to reach close to 25 million pairs/year (Graph VI.2a) a figure that was higher than those recorded for all years before 1998.

Graphs VI.1b and VI.1c show imports of “nonsport footwear” and "sport footwear” respectively. Non sports footwear imports are significantly lower than those of sports footwear, and they remained quite constant while the WTO safeguard measures were in force between early 1997 and 2000. However, during this period, the trade diversion process towards Mercosur intensified.

Concerning sports footwear, imports grew by around 50\% between 1995 and 2001, with an increasing share of purchases from Mercosur. As a consequence of this process, the sports footwear industry suffered a great business deterioration. In recent years, the main

companies have faced insolvency situations, seizure of factories by workers and critical situations in some urban centers where employment is heavily dependent on this industry.

Nevertheless for these industries, the turnaround came in 2002 with the devaluation of the peso that lowered imports to a far greater than any of the relief and safeguards measures discussed above (Graphs VI.1 and VI.2). Although during 2003 and 2004 imports have recovered somewhat, they remain below the levels recorded in the recession years that started in late 1998. Furthermore, the greater competitiveness has generated interest in reactivating the domestic industry and since then, there have been agreements to manufacture products locally under international brands that had previously been importing 
from Asia and Brazil ${ }^{39}$. Unlike the successive safeguard measures, devaluation had a very clear impact on sports footwear imports.

Concerning the non sports footwear segment, after several years of decline, it also experienced an important recovery boosted by the devaluation. However, imports from Brazil remain important and continue to generate claims for relief from the Argentine industry.

Summing up, it is quite clear that the devaluation has been far more successful in reducing imports than any of the contingent protection measures implemented in earlier years. Nevertheless, the industry continues to experience competitiveness problems. This may be related to the defective and uncertain safeguard measures under which the industry never confronted a situation when it could count on a certain number of years and height of measures under which it could had developed an adjustment program. The future of the industry continues to pose questions and it will strongly depend on the transformations that it is capable of implementing under the breathing space offered by the devaluation of the peso.

\section{Lessons}

During the trade liberalization process initiated in the late 1980s, and particularly after the WTO agreements came into force, Argentina's footwear industry could not count on a predictable safeguard mechanism that perhaps would have enabled it to implement an orderly adjustment to become internationally competitive. The import-relief measures have been of uncertain duration and threatened by decisions from the WTO Appellate Body. Based on the analysis of this experience, we offer the following lessons:

\footnotetext{
${ }^{39}$ According to Consejo Técnico de Inversiones S.A. (2002), in 2002 the following companies launched new projects: Grimoldi, in joint venture with Wolverini, Adidas, Alpargatas in agreement with FILA, Union, and Dexter Shops and Nike in agreement with Gatic.
} 


\section{a) Safeguards and exchange rate policy}

In the last few years, Argentina opened its economy unilaterally while at the same time its currency became overvalued. In this process, labor-intensive industries such as textiles and footwear, which had been strongly protected for many decades, faced an important increase in import competition. Confronted with this problem, the government provided temporary relief measures first through the DIEMs and later with the WTO safeguard measures. The evidence indicates that the impact of these policies on imports was only a fraction of the effects that the early 2002 devaluation of the peso had (Graphs VI.1a and VI.2a). The lesson here is that a flexible exchange rate regime would had been a more effective import-relief policy than any of those that were actually implemented.

\section{b) Regional safeguards}

The safeguards applied by Argentina in favor of its footwear industry to imports from third countries created important trade-diversion effects in favor of Mercosur. Given Brazil's status as a major footwear exporter and the absence of a safeguard instrument to facilitate intra-regional adjustment, the discriminatory import-relief measures became a weak and quite ineffective relief policy. The lesson here is that member countries underestimated the costs and length of time required for adjusting to free intra-regional trade. Unlike Mercosur, most other regional agreements have adopted some form of adjustment-smoothing policies.

\section{c) WTO Safeguards and trade liberalization}

Under GATT and before the Uruguay Round agreements were signed, Argentina had a high degree of freedom to regulate the speed of its unilateral trade liberalization policies according to the political and economic considerations that policymakers considered adequate to maintain support in favor of trade liberalization. This situation changed radically when the WTO agreements became effective.

It is likely that Argentina's authorities expected that while import barriers were being lowered, the safeguard mechanism that was under negotiation in the Uruguay Round would serve to manage the trade liberalization program. If so, this assumption 
turned out to be wrong. The new Agreement on Safeguards and Article XIX (1) of GATT94 do not provide a clear multilateral framework to implement measures. In addition, the decisions by the Appellate Body have not clarified the economics of WTO safeguards. Furthermore, these decisions have severely restricted the use of safeguards in a way that strengthens the voice of those that are against liberalization.

Broad unilateral trade liberalization programs like those implemented by many developing countries should constitute the base against which to assess the increase in imports and the implementation of relief measures. Under these types of programs, there will always be unforeseen developments and adjustment processes of uncertain duration. With the WTO jurisprudence that has been established by its Appellate Body, developing countries have been stripped of a powerful argument to convince their political sectors of the advantages of opening their economies.

\section{d) Ambiguous multilateral agreements}

Article XIX and the Agreement on Safeguards do not offer a clear framework of rules for implementing safeguard measures. The lesson here well stated by Sykes (2003) is that it is a serious error to negotiate ambiguous multilateral agreements on the expectation that at a later date the WTO Dispute Settlement Mechanism will clarify them. 


\section{References}

ALADI (2002), Probable Impacto que Tendrían los Acuerdos con la Unión Europea en el Comercio Intrarregional y en el Comercio de los Países Miembros con los Países de Europa, ALADI/SEC/Estudio 149.

AMERICAN APPAREL \& FOOTWEAR ASSOCIATION (2004), Shoe Stats 2003. www.apparelandfootwear.org, AAFA.

BEKERMAN, M. et al. (2000), El impacto sectorial del proceso de integración subregional en el MERCOSUR: sector calzado y sector farmacéutico, INTAL, Buenos Aires.

CERUTTI, J. (2003) Industria del calzado. CEPAL and Ministry of Economy of Argentina. Buenos Aires.

CNCE (1997), Acta No 338 e Informe Técnico Gerencia de Investigaciones. Salvaguardia Industria del Calzado, CNCE: Buenos Aires.

CONSEJO TÉCNICO DE INVERSIONES S.A. (2002), “Tendencias Económicas y Financieras,” Buenos Aires.

DE LA TORRE, A., E. LEVI YEYATI AND S. SCHMUKLER (2003), Living and Dying with Hard Pegs: The Rise and Fall of Argentina's Currency Board, Economía, Vol. 5, No. 2.

DE PAIVA ABREU, M. (1996), Trade in Manufactures: the Outcome of the Uruguay Round and Developing Country Interests, in Martin, Will and L. Alan Winters (1996), "The Uruguay Round and the Developing Countries," Cambridge University Press.

EUROPEAN CONFEDERATION OF THE FOOTWEAR INDUSTRY (1995), Research Strategy for the European Footwear Industry. www.cecshoe.be .

FINGER, J. (2002), Safeguards: Making Sense of GATT/WTO Provisions Allowing for Import Restrictions, in Hoekman, B., A. Mattoo, and P. English (eds.) "Development, Trade, and the WTO: A Handbook,” The World Bank. Washington, D.C.

GEREFFI, G. (2001), Las cadenas productivas como marco analítico para la globalización, Problemas del Desarrollo, Vol.32, núm. 125, IIEc-UNAM, Mexico.

HUFBAUER, G. AND K. ELLIOT (1994), Measuring the Costs of Protection in the United States, Institute for International Economics: Washington DC.

NOGUÉS, J. (2001), La Institucionalización de la Globalización: in De Pablo, J., R. Dornbusch and J. Nogués, La Globalización, la Argentina y Cada Uno de Nosotros, Consejo Empresario Argentino (CEA): Buenos Aires. 
NOGUÉS, J. AND E. BARACAT (2005), The Political-Economy of Antidumping and Safeguard Measures in Argentina, World Bank Staff Working Paper (forthcoming): Washington DC.

PAUWELYN, J., (2003), The Puzzle of WTO Safeguards and Regional Trade Agreements, Journal of International Economic Law. Oxford (UK).

REINA, M. (2005), Aplicación de Salvaguardias y Derechos Antidumping en Colombia, World Bank Staff Working Papers (forthcoming): Washington DC.

SÁEZ, S., (2005): Keeping Animal Spirits Asleep: The Case of Chile, World Bank Staff Working Papers (forthcoming).

SALAZAR DE BUCKLE, T. (2001), The Leather Global Value Chain and The World Leather Footwear Market, Report to UNIDO, Vienna.

SHETTY, S. (1995), Structural Changes and Competitive Strategies of the U.S. Footwear Industry in the 1990's, U.S. Department of Commerce: Washington DC.

SYKES, A. (2003), The Safeguard Mess: A Critique of WTO Jurisprudence, World Trade Review, 2, 3, November.

SYKES, A. (2004), The Persistent Puzzles of Safeguards: Lessons From the Steel Dispute, mimeo.

TRADE DEVELOPMENT COUNCIL (2003) Hong Kong'sKong's Footwear Industry, www.TDCtrade.com , Hong Kong.

U.S. INTERNATIONAL TRADE COMMISSION (1999) Non-rubber Footwear Statistical Report, Investigation No. 332-191, ITC: Washington DC.

WTO (1996), The Results of the Uruguay Round of Multilateral Trade Negotiations, World Trade Organization: Geneva.

WTO (1999), ArgentinaSafeguard Measures on Imports of Footwear: Report by the Panel, WTO, WT/DS121/R: Geneva.

WTO (1999a), ArgentinaSafeguard Measures on Imports of Footwear: Report of the Appellate Body, WTO, WT/DS121/AB/R. 
Table II.1: Ad-valorem Tariffs and Import Licenses, 1980 -1992

\begin{tabular}{|c|c|c|c|c|}
\hline \multirow{2}{*}{ Year } & \multicolumn{3}{|c|}{ Tariff (\%) } & \multirow{2}{*}{$\begin{array}{c}\text { Import } \\
\text { Licenses (\%)* }\end{array}$} \\
\hline & Maximum & Surcharge & Average & \\
\hline 1980 & 100 & 0 & 25 & 0 \\
\hline 1981 & 75 & 0 & 29 & 0 \\
\hline 1982 & 55 & 0 & 30 & 4 \\
\hline 1983 & 55 & 0 & 30 & 15 \\
\hline 1984 & 55 & 0 & 30 & 51 \\
\hline 1985 & 55 & 10 & 32 & 52 \\
\hline 1986 & 55 & 10 & 39 & 47 \\
\hline 1987 & 50 & 15 & 39 & 51 \\
\hline 1988 & 50 & 15 & 39 & 32 \\
\hline 1989 & 30 & 0 & 18 & 0 \\
\hline 1990 & 24 & 0 & 17 & 0 \\
\hline 1991 & 35 & 0 & 12 & 0 \\
\hline 1992 & 35 & 0 & 11,8 & 0 \\
\hline
\end{tabular}

* Percent of tariff lines covered.

Source: Nogués, 2001 (p.85). 
Figure II.1: Real Exchange Rate, 1985- 2002

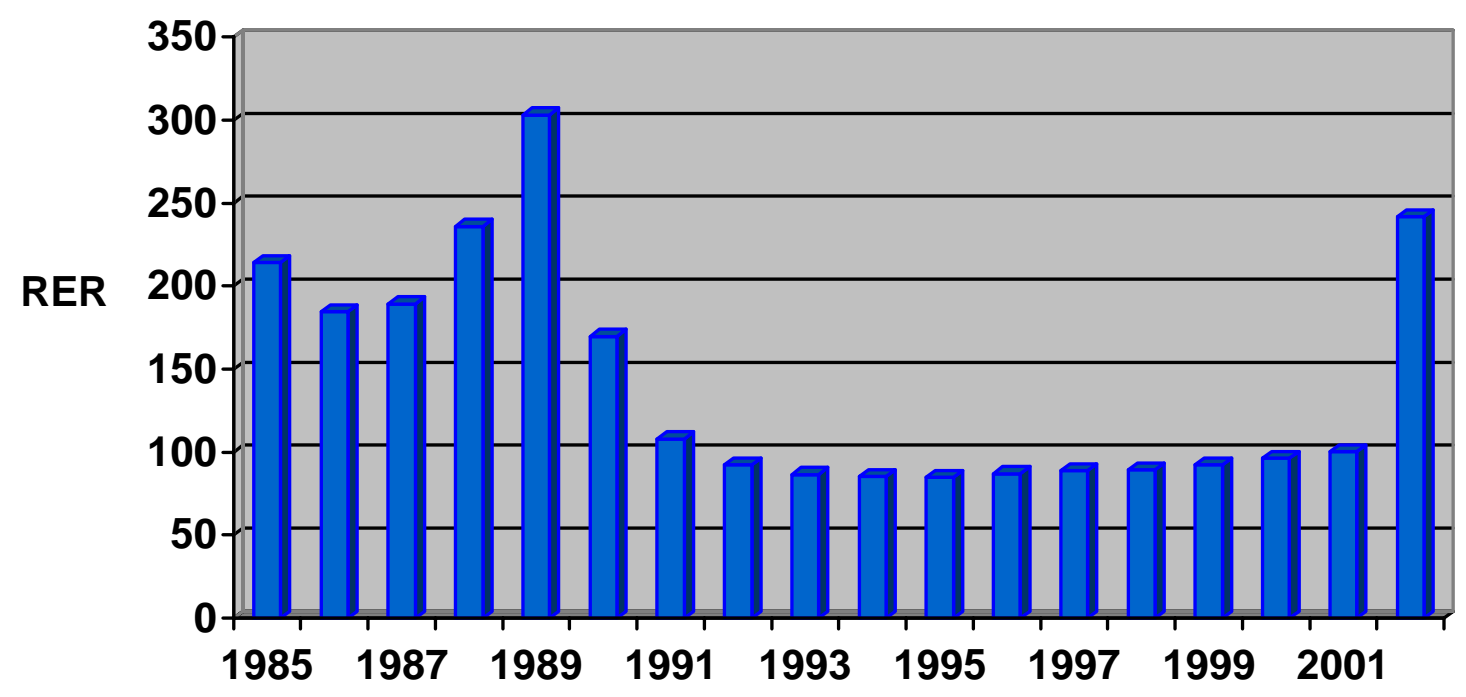

Source: Nogués and Baracat (2005).

Figure II.2: Trade Flows (millions of U\$S)

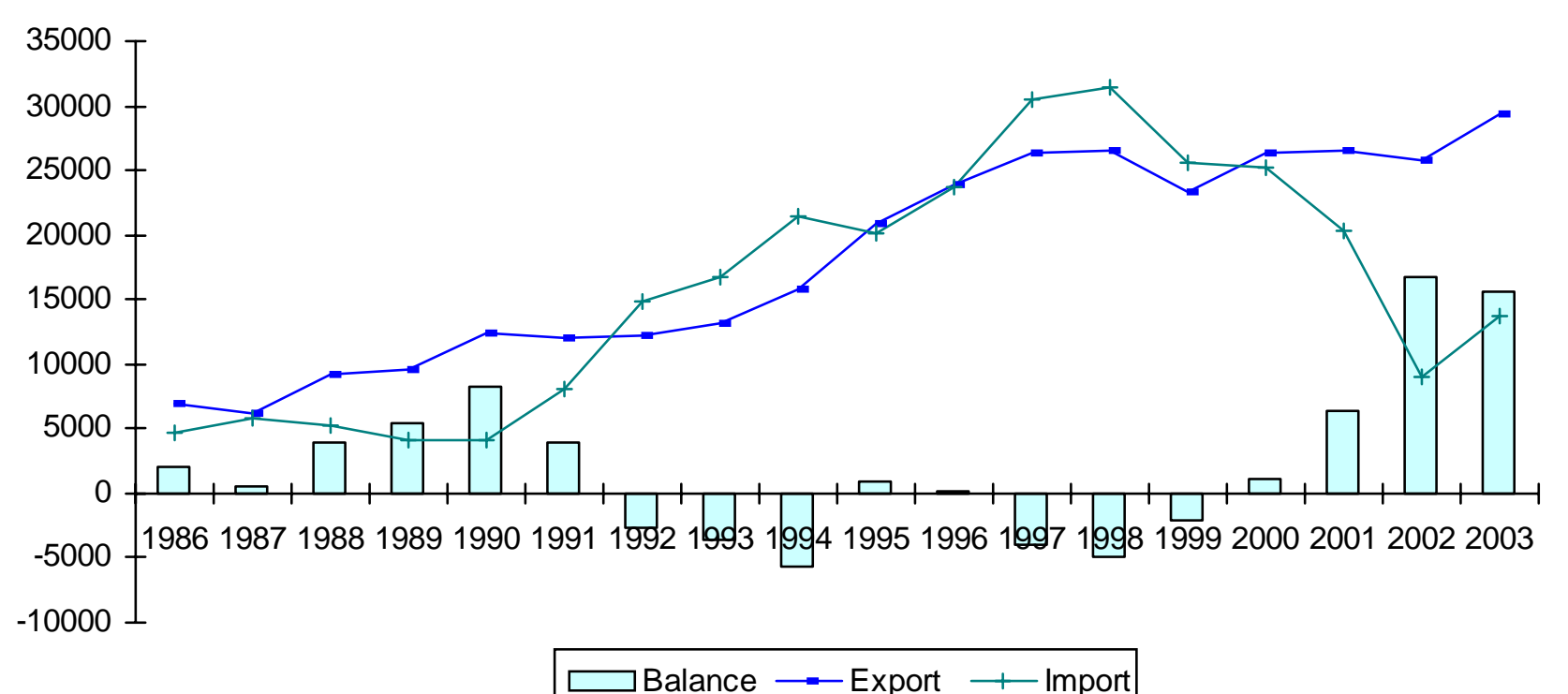

Source: INDEC (Instituto Nacional de Estadísticas y Censos). 


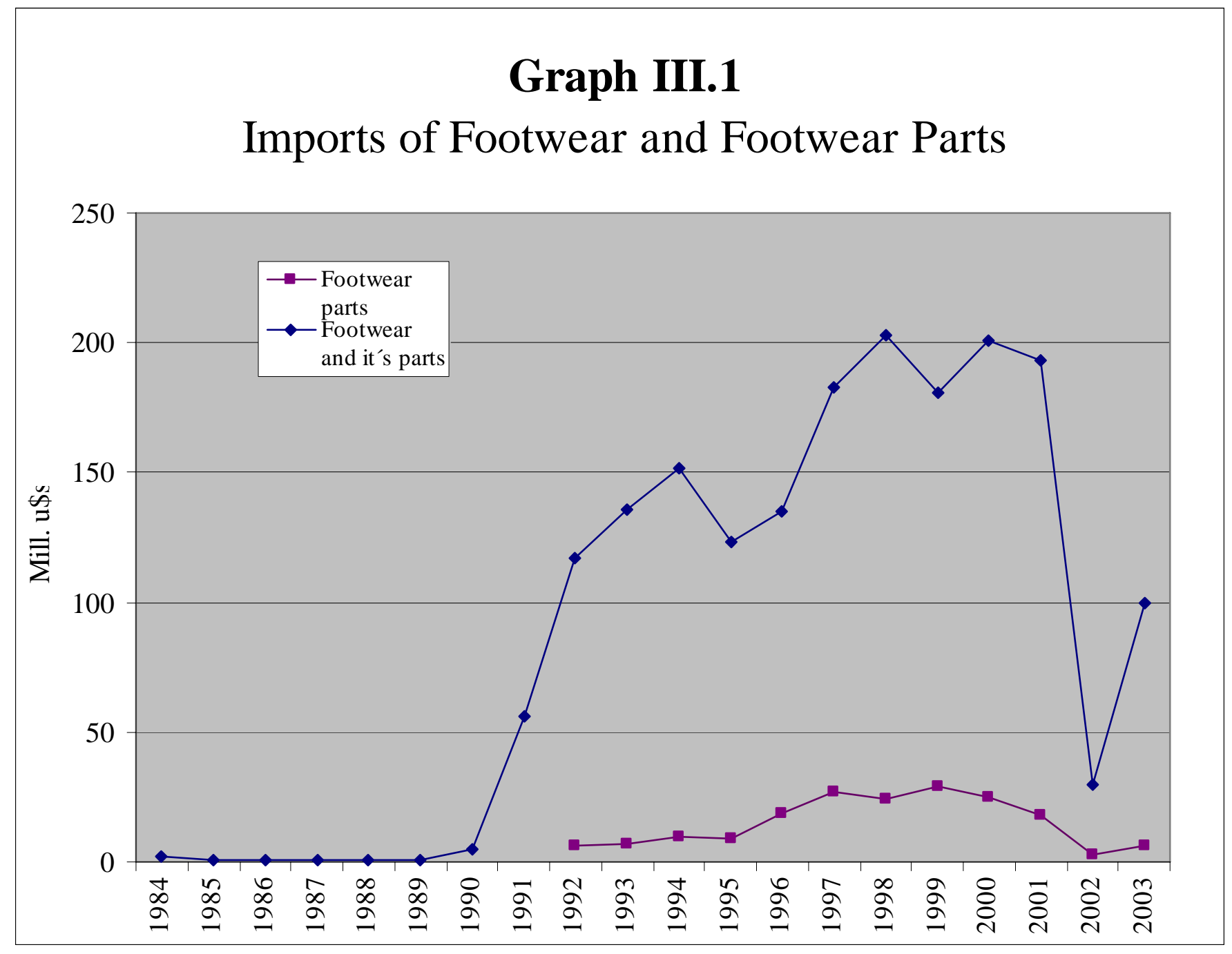

Source: Authors' elaboration based on INDEC. 


\section{Graph III.2 \\ Exports of Footwear and Parts}

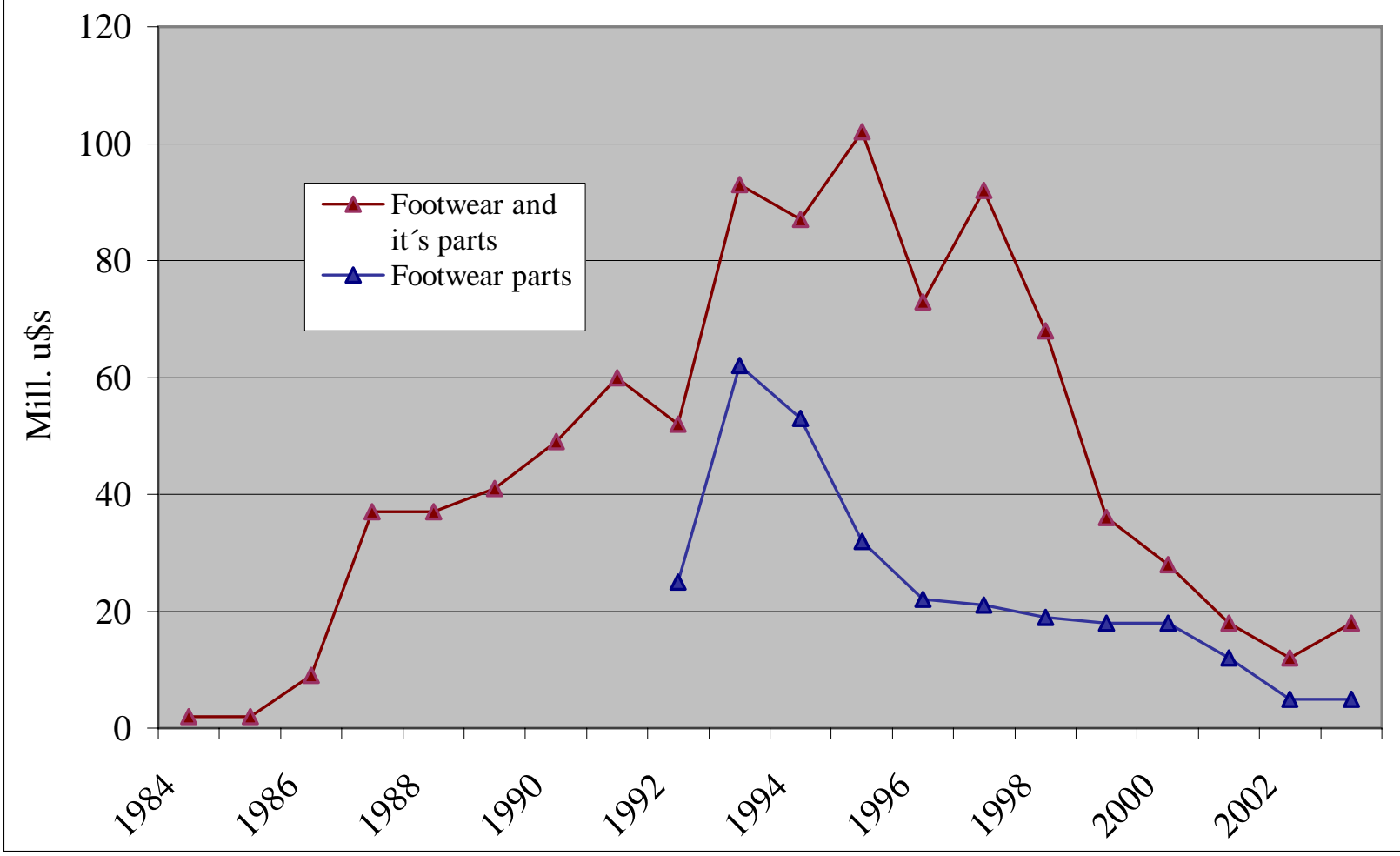

Source: Authors' elaboration based on INDEC. 
Table III.1: Imports of Finished Footwear

\begin{tabular}{|l|l|l|l|l|l|l|}
\hline Origins & $\mathbf{1 9 9 1}$ & $\mathbf{1 9 9 2}$ & $\mathbf{1 9 9 3}$ & $\mathbf{1 9 9 4}$ & $\mathbf{1 9 9 5}$ & $\mathbf{1 9 9 6}$ \\
\hline Total imports & 8.86 & 16.63 & 21.78 & 19.84 & 15.07 & 13.47 \\
\hline Mercosur & 1.90 & 3.97 & 5.08 & 5.83 & 4.99 & 7.50 \\
\hline Third countries & 6.96 & 12.66 & 16.70 & 14.01 & 10.07 & 5.97 \\
\hline
\end{tabular}

Source: Authors' elaboration based on the WTO (1999).

Table V.1: Import Volumes (millions of pairs)

\begin{tabular}{|c|c|c|c|}
\hline Year & $\begin{array}{c}\text { Quantity } \\
\text { millions of } \\
\text { pairs }\end{array}$ & $\begin{array}{c}\text { Value } \\
\text { millions of u\$s }\end{array}$ & $\begin{array}{c}\text { Unit Value } \\
\text { in u\$s }\end{array}$ \\
\hline $\mathbf{1 9 9 1}$ & 8.86 & 44.41 & 5.01 \\
\hline $\mathbf{1 9 9 2}$ & 16.63 & 110.87 & 6.67 \\
\hline $\mathbf{1 9 9 3}$ & 21.78 & 128.76 & 5.91 \\
\hline $\mathbf{1 9 9 4}$ & 19.84 & 141.48 & 7.13 \\
\hline $\mathbf{1 9 9 5}$ & 15.07 & 114.22 & 7.58 \\
\hline $\mathbf{1 9 9 6}$ & 13.47 & 116.61 & 8.66 \\
\hline
\end{tabular}

Source: Report of the Special Group (WTO 1999). 

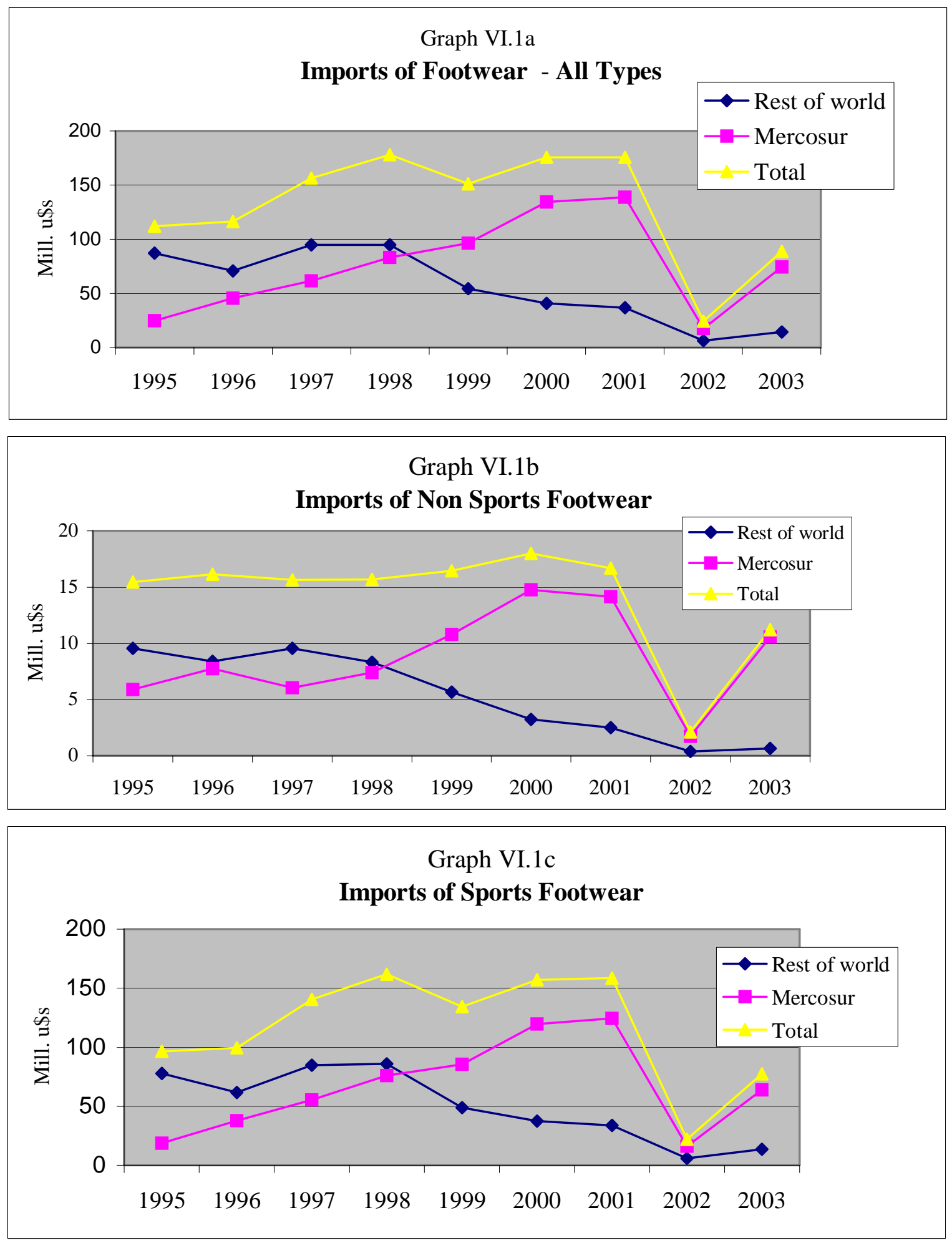

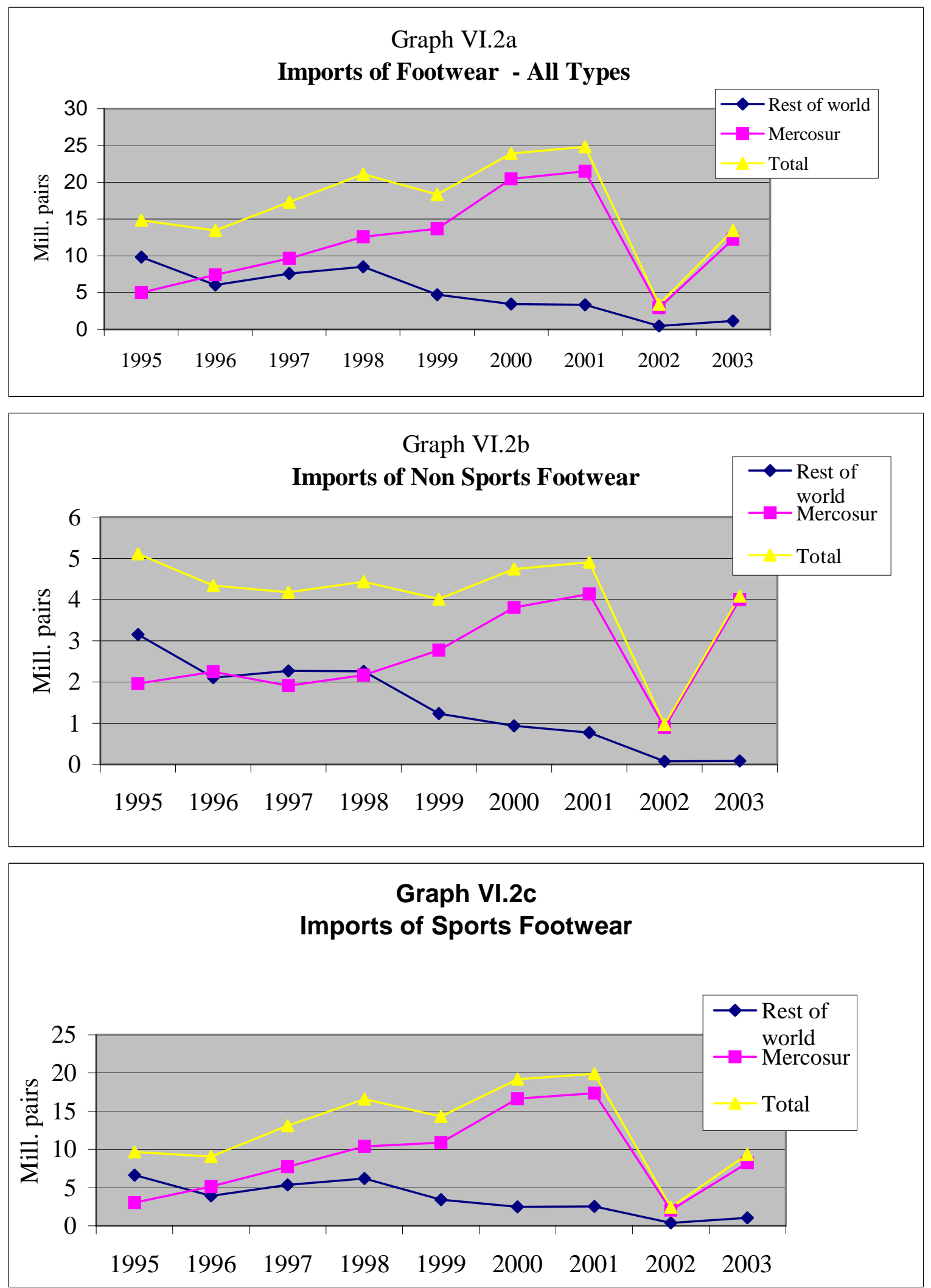

Source: Authors' elaboration based on INDEC. 